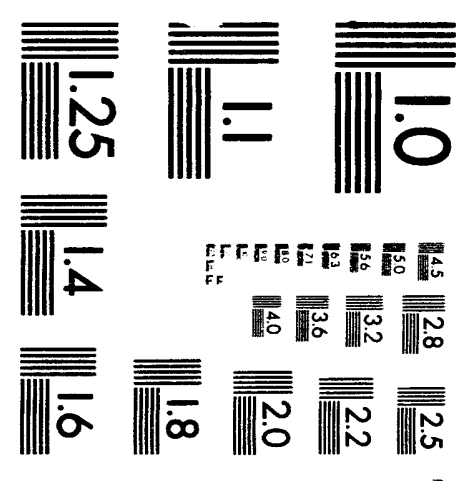



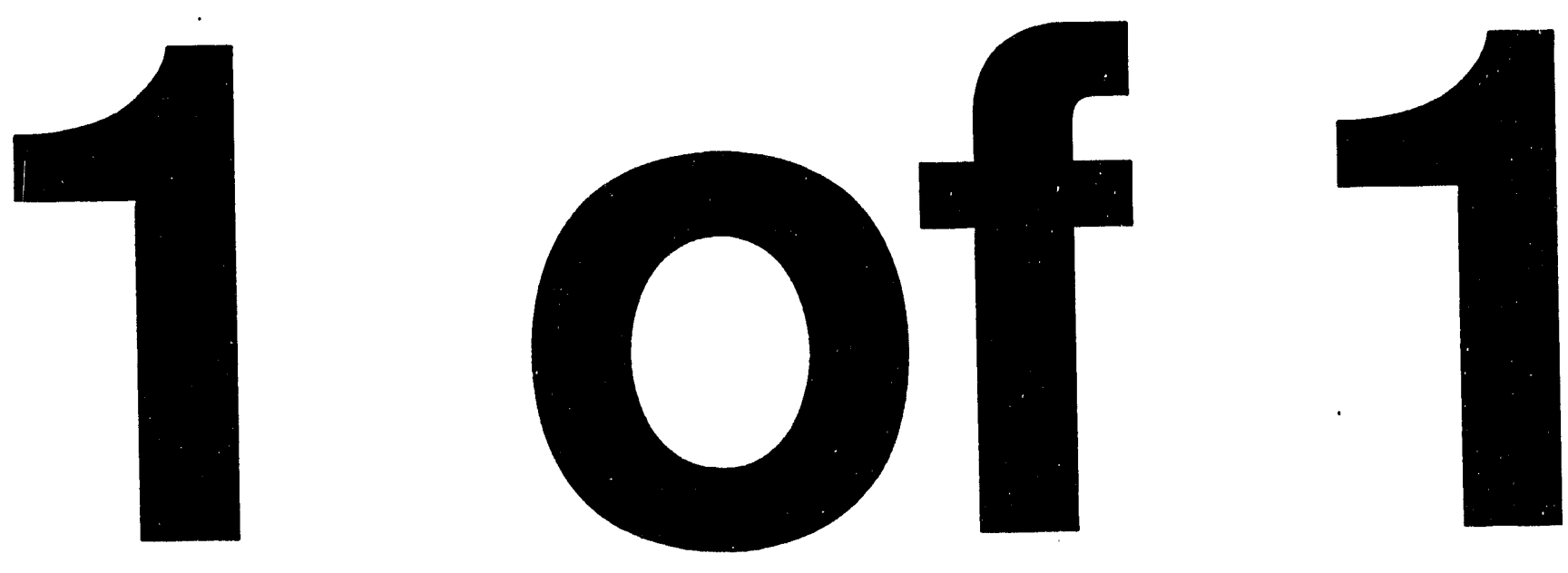


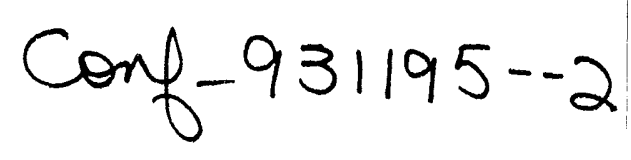

PNL-SA-22432

REACTION SEQUENCES IN SIMULATED NEUTRALIZED CURRENT ACID WASTE SLURRY DURING PROCESSING WITH FORMIC ACID

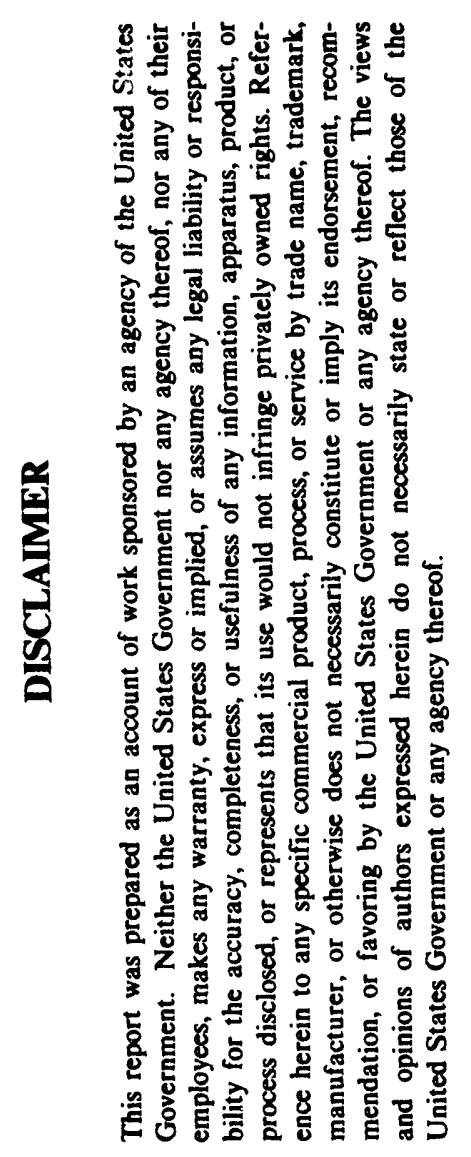
H. D. Smith
K. D. Wiemers
M. H. Langowski
M. R. Powel1
D. E. Larson

November - December 1993

Presented at the

Scientific Basis for Nuclear Waste Management XVII Conference

November 29 - December 3, 1993

Boston, Massachusetts

Work supported by

the U.S. Department of Energy under Contract DE-ACO6-76RLO 1830

Pacific Northwest Laboratory

Richland, Washington 99352

\section{MASTER}

S UEL 301993

DISTRABUTION OF THIS DOCUMENT IS UNLIMITED O S T I 


\title{
REACTION SEQUENCES IN SIMULATED NEUTRALIZED CURRENT ACID WASTE SLURRY DURING PROCESSING WITH FORMIC ACID
}

\author{
H.D. SMITH, K.D. WIEMERS, M.H. LANGOWSKI, M.R. POWELL, and D.E. LARSON \\ Pacific Northwest Laboratory, Richland, WA 99352
}

\begin{abstract}
The Hanford Waste Vitrification Plant (HWVP) is being designed for the Department of Energy to immobilize high-level and transuranic wastes as glass for permanent disposal. Pacific Northwest Laboratory is supporting the HWVP design activities by conducting laboratory-scale studies using a HWVP simulated waste slurry. Conditions which affect the slurry processing chemistry were evaluated in terms of offgas composition and peak generation rate and changes in slurry composition. A standard offgas profile defined in terms of three reaction phases, decomposition of $\mathrm{H}_{2} \mathrm{CO}_{3}$, destruction of $\mathrm{NO}_{2}{ }^{\circ}$, and production of $\mathrm{H}_{2}$ and $\mathrm{NH}_{3}$ was used as a baseline against which changes were evaluated. The test variables include nitrite concentration, acid neutralization capacity, temperature, and formic acid addition rate. Results to date indicate that $\mathrm{pH}$ is an important parameter influencing the $\mathrm{N}_{2} \mathrm{O} / \mathrm{NO}_{x}$ generation ratio; nitrite can both inhibit and activate rhodium as a catalyst for formic acid decomposition to $\mathrm{CO}_{2}$ and $\mathrm{H}_{2}$; and a separate reduced metal phase forms in the reducing environment. These data are being compiled to provide a basis for predicting the HWVP feed processing chemistry as a function of feed composition and operation variables, recommending criteria for chemical adjustments, and providing guidelines with respect to important control parameters to consider during routine and upset plant operation.
\end{abstract}

\section{INTRODUCTION}

High-level radioactive wastes on the Hanford (Washington) site presently reside in underground tank facilities that are recognized as temporary storage. It is planned to permanently dispose of the high-level and transuranic wastes by incorporating them into a durable borosilicate glass matrix which, with accompanying engineered barriers, makes a degradation resistant waste package suitable for burial in an appropriate geologic setting. Vitrification will be carried out in the Hanford Waste Vitrification Plant (HWVP).

The waste is incorporated into a glass melter feed slurry in a multi-step process. One of those steps consists of adjusting the $\mathrm{pH}$ and redox potential of the waste with the addition of an organic acid $(\mathrm{HCOOH})$.

The generation of $\mathrm{H}_{2}$ and $\mathrm{NH}_{3}$ has been observed during the processing of simulated Hanford waste slurry with $\mathrm{HCOOH}$ (Wiemers 1988). Ritter et al. (1992) have observed similar gas generation phenomena at the Savannah River waste vitrification pilot-scale facility. The reaction sequences during slurry processing, focusing on $\mathrm{H}_{2}$ and $\mathrm{NH}_{3}$ generation, are under investigation with the objective of mitigating the hazards associated with these compounds. Hydrogen generation can lead to serious safety issues because of the possibility of producing flammable gas mixtures. Ammonia generation can also result in serious safety issues through the production of $\mathrm{NH}_{4} \mathrm{NO}_{3}$, an unstable, strong oxidizer particularly in the presence of organic compounds. This paper, prepared by staff at Pacific Northwest Laboratory (PNL), ${ }^{(a)}$ discusses the results of

(a) Pacific Northwest Laboratory is operated for the U. S. Department of Energy by Battelle Memorial Institute under Contract DE-AC06-76RLO 1830. 
treating simulated Neutralized Current Acid Waste (NCAW) slurry (represents wastes resulting from the reprocessing of spent reactor fuel) with $\mathrm{HCOOH}$ under several variations of the reference processing conditions.

\section{METHOD}

The target composition and source chemicals for the NCAW slurry simulant are given in Table I. The slurry simulant preparation procedure followed steps that would approximate the production of the actual waste (Peterson et al. 1989), i.e., an acid nitrate solution containing many of the elements was made basic with $\mathrm{NaOH}$ and then washed to the proper nitrate level; $\mathrm{NaNO}_{2}$ and $\mathrm{Na}_{2} \mathrm{CO}_{3}$ were added to achieve target levels.

Simulated waste slurry was treated with $\mathrm{HCOOH}$ using a laboratory-scale system and test steps simulating the slurry processing that will occur in the Hanford Waste Vitrification Plant slurry receipt and adjustment tank (SRAT) and slurry mix evaporator (SME). About $1.5 \mathrm{~L}$ of slurry containing between 125 and $140 \mathrm{~g}$ of waste oxide per $\mathrm{L}^{(\mathrm{b})}$ was placed in a $2-\mathrm{L}$ pyrex reaction vessel and boiled for at least $10 \mathrm{~min}$ to remove dissolved gases. Then a predetermined amount of $\mathrm{HCOOH}$ was added to the slurry at a specific rate (e.g., $13.5 \mathrm{mM} / \mathrm{min}$ ) at the test temperature. After the $\mathrm{HCOOH}$ addition was completed, the treated slurry was "digested" by boiling for $4 \mathrm{~h}$. The offgas was measured continuously from the beginning of $\mathrm{HCOOH}$ addition to the shutdown of the test. Conditions for nine tests described in this paper are summarized in Table II.

The offgas composition was determined by periodically analyzing an Ar sweep gas flowing through the headspace of the reaction vessel during the slurry processing. The offgas analytical system consisted of tuned infrared detectors for $\mathrm{CO}_{2}, \mathrm{CH}_{4}, \mathrm{~N}_{2} \mathrm{O}$, and $\mathrm{NO}_{x}$, and a gas chromatograph to measure $\mathrm{H}_{2}$. Methane, injected downstream from the reaction vessel, was used as a tracer gas to calculate total gas volume. Chemical analyses of slurry and condensate samples, including a determination of the amounts of $\mathrm{HCOO}^{-}, \mathrm{NO}_{2}^{-}$, and $\mathrm{NO}_{3}$ using ion chromatography and $\mathrm{NH}_{4}^{+}$ using a selective ion electrode, complimented the offgas data.

\section{RESULTS AND DISCUSSION}

\section{HWVP NCAW Slurry Processing Chemistry}

The offgas profiles, such as those shown in Figure 1, reflect the progression of chemical reactions that are believed to occur as $\mathrm{HCOOH}$ is added to the alkaline NCAW slurry. Three reaction stages have been observed and are characterized by specific chemical reactions as follows:

$$
\begin{array}{ll}
\text { Stage I } & \mathrm{H}_{2} \mathrm{CO}_{3} \cdots \cdots-.->\mathrm{H}_{2} \mathrm{O}+\mathrm{CO}_{2} \uparrow \\
& \log \left\{\left[\mathrm{H}_{2} \mathrm{CO}_{3}\right] /\left[\mathrm{HCO}_{3}^{-}\right]\right\}=6.45-\mathrm{pH}\left(\text { at } 100^{\circ} \mathrm{C}\right. \text { [Helgeson 1967]) } \\
\text { Stage II } & 3 \mathrm{HNO}_{2} \cdots \ldots-\ldots \mathrm{H}^{+}+\mathrm{NO}_{3}^{-}+2 \mathrm{NO} \uparrow+\mathrm{H}_{2} \mathrm{O} \\
& \log \left\{\left[\mathrm{HNO}_{2}\right] /\left[\mathrm{NO}_{2}^{-}\right]\right\}=3.35-\mathrm{pH}\left(25^{\circ} \mathrm{C}\right) \\
& 2 \mathrm{HNO}_{2}+2 \mathrm{NaCOOH} \cdots>\mathrm{N}_{2} \mathrm{O} \uparrow+2 \mathrm{CO}_{2} \uparrow+2 \mathrm{NaOH}+\mathrm{H}_{2} \mathrm{O} \\
& 2 \mathrm{HNO}_{2}+\mathrm{NaCOOH} \cdots>2 \mathrm{NO} \uparrow+\mathrm{CO}_{2} \uparrow+\mathrm{NaOH}+\mathrm{H}_{2} \mathrm{O}
\end{array}
$$

(b) Grams of waste oxide per liter ( $\mathrm{gWO} / \mathrm{L}$ ) is the weight of the oxide residue that would result from drying and then calcining $1 \mathrm{~L}$ of slurry simulant at $1050^{\circ} \mathrm{C}$ for $2 \mathrm{~h}$. 
Table I. NCAW Slurry Simulant Target Composition and Source Chemicals

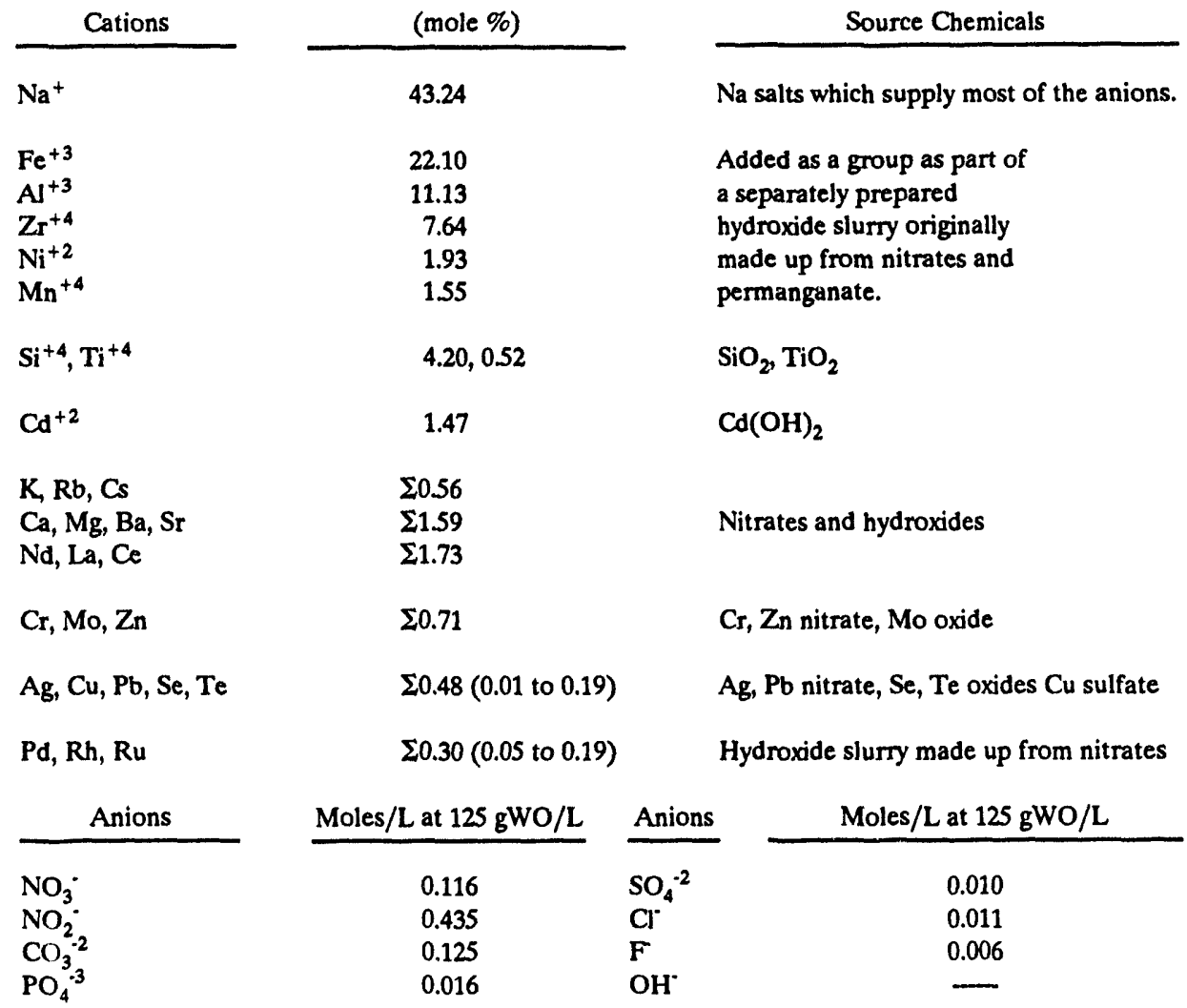

Table II. Conditions for Nine Laboratory-scale HWVP Feed Preparation Tests with an NCAW Simulant

\begin{tabular}{l}
\multicolumn{1}{c}{ Test Parameter } \\
\hline Test \\
HCOOH Add. Amount $(\mathrm{M})$ \\
HCOOH Add. Rate $(\mathrm{mM} / \mathrm{min})$ \\
HCOOH Add. Temp. $\left({ }^{\circ} \mathrm{C}\right)$ \\
Digestion Temp. $\left({ }^{\circ} \mathrm{C}\right)$ \\
Duration (h) \\
Slurry Composition \\
Modification \\
Add NaOH $(\mathrm{M})$ \\
Nitrite - \% nominal
\end{tabular}

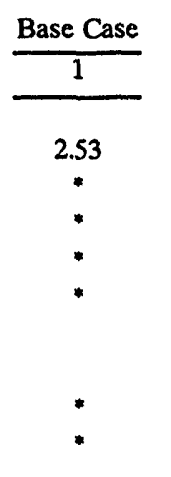

\begin{tabular}{|c|c|c|c|c|c|c|c|}
\hline \multicolumn{3}{|c|}{ Acid-Base Neutralization } & \multicolumn{3}{|c|}{ Temperature } & \multirow{2}{*}{$\frac{\text { HCOOH Add Rate }}{8}$} & \multirow{2}{*}{$\frac{\mathrm{NO}_{2}^{-}}{9}$} \\
\hline 2 & 3 & 4 & 5 & 6 & 7 & & \\
\hline 2.56 & 1.96 & 2.45 & 2.29 & 2.29 & 2.29 & 2.22 & 1.22 \\
\hline${ }^{*}$ & * & * & & - & * & 5.3 & 10.9 \\
\hline * & * & * & 85 & 85 & 75 & * & * \\
\hline * & * & $*$ & $*$ & $85^{*}$ & $75^{*}$ & * & * \\
\hline * & * & $*$ & * & 2,4 & 2,4 & * & * \\
\hline
\end{tabular}

*nominal test conditions:

HCOOH Add. Rate ( $\mathrm{mM} / \mathrm{min})-13.5$

HCOOH Add. Temp. $\left({ }^{\circ} \mathrm{C}\right)-95$

Digestion Temp. - boiling conditions $\left(101^{\circ} \mathrm{C}\right.$ to $\left.102^{\circ} \mathrm{C}\right)$

Digestion Duration (h) -4

Slurry Composition

Modification

Add $\mathrm{NaOH}(\mathrm{M})-0$

Nitrite - \% nominal - $100 \%$ ( 0.435 moles $/ \mathrm{L}$ at $125 \mathrm{gWO} / \mathrm{L})$ 


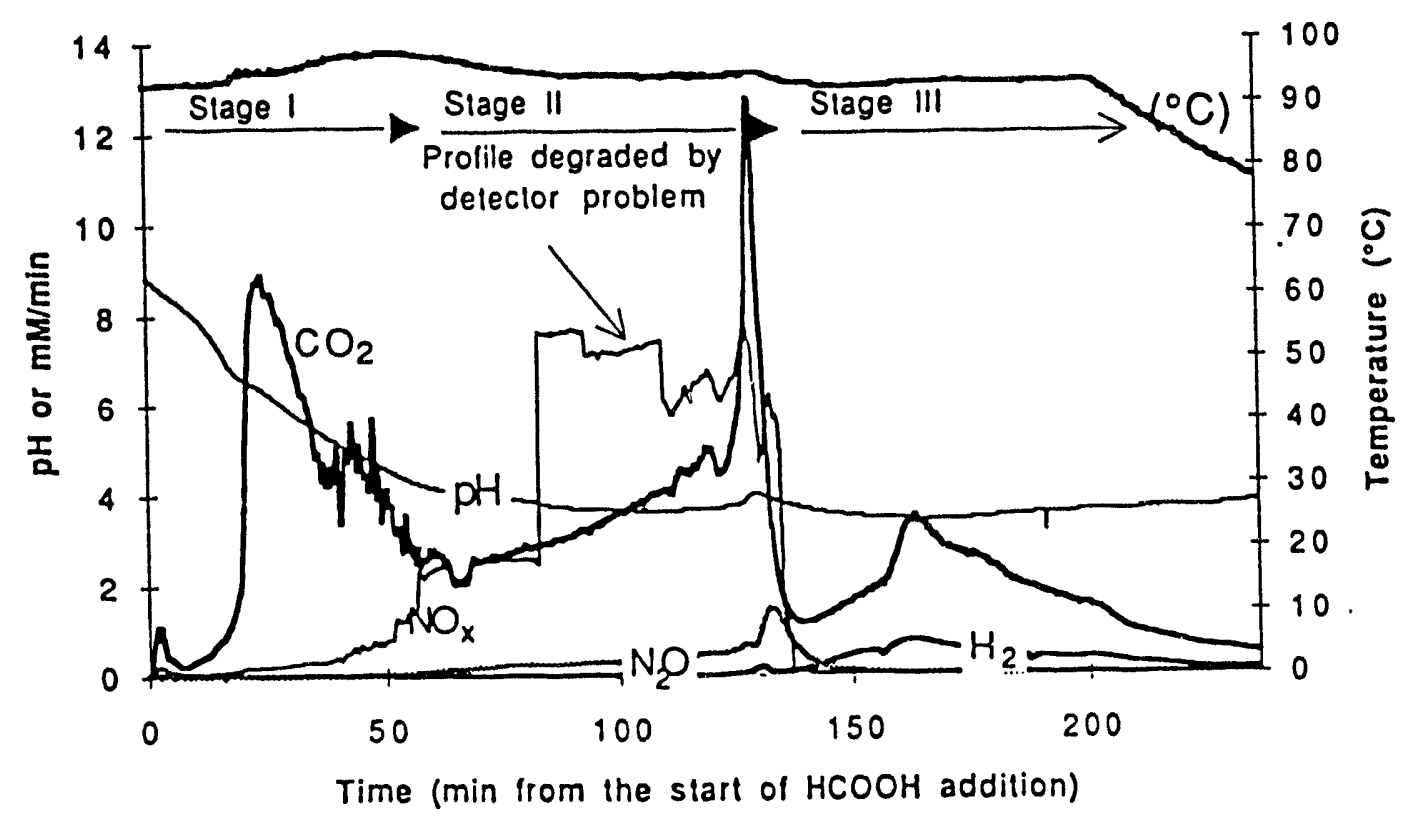

Figure 1. Baseline $\mathrm{HCOOH}$ Addition Test. Formic acid was added constantly at $13.5 \mathrm{mM} / \mathrm{min}$ starting at time zero. Detector problem degraded $\mathrm{NO}_{\mathrm{x}}$ data, but start and finish are accurately indicated. Length of labeled arrow near top of figure indicates the extent of each reaction stage. Stage III continued to the end of the test.

Stage III $\mathrm{HCOOH}-\cdots-\cdots-\cdots-\mathrm{CO}_{2} \uparrow+\mathrm{H}_{2} \uparrow$ (catalyzed)

$$
\begin{aligned}
& \mathrm{NO}_{3}^{-}+5 \mathrm{HCOOH} \ldots . .->\mathrm{NH}_{3}+4 \mathrm{CO}_{2} \uparrow+\mathrm{COOH}^{-}+3 \mathrm{H}_{2} \mathrm{O} \\
& \mathrm{Me}^{+3}+3 \mathrm{e}^{-}-\ldots-\ldots-\ldots-.->\mathrm{Me}^{0} \quad \text { (black residue) }
\end{aligned}
$$

Reactions (1) and (2) progress as the slurry is acidified with $\mathrm{HCOOH}$. Based on the dissociation constants, $\mathrm{H}_{2} \mathrm{CO}_{3}$ (Equation 1) would be expected to decompose before $\mathrm{HNO}_{2}$ (Equation 2). Reactions (3) and (4) are redox reactions between $\mathrm{NO}_{2}^{-}$and $\mathrm{HCOOH}$. Initiation of $\mathrm{NO}$ generation marks the shift into Stage II. Reduction of $\mathrm{NO}_{2}^{-}$to $\mathrm{N}_{2} \mathrm{O}$ (Equation 3) predominates at $\mathrm{pH}>\sim 6$ and reduction of $\mathrm{NO}_{2}^{-}$to $\mathrm{NO}$ (Equation 4) is favored at $\mathrm{pH}<\sim 6$. Transition from Stage II to Stage III is believed to be, in part, due to depletion of $\mathrm{NO}_{2}^{-}$to a "critical level." At this critical $\mathrm{NO}_{2}^{-}$level, significant generation of $\mathrm{H}_{2}$ from noble metal catalyzed decomposition of $\mathrm{HCOOH}$ (Equation 5) and reduction of $\mathrm{NO}_{3}^{-}$to $\mathrm{NH}_{3}$ (Equation 6) begin. A characteristic of Stage III is that significant amounts of $\mathrm{H}_{2}$ and $\mathrm{NH}_{3}$ are generated.

Rhodium is the most active catalyst for the decomposition of $\mathrm{HCOOH}$ into $\mathrm{CO}_{2}$ and $\mathrm{H}_{2}$ in neutralized high-level waste, Reaction (5). King (1993) has shown that Rh can be inhibited or activated, depending on the concentration of $\mathrm{NO}_{2}^{-}$in the slurry. The transition from inhibited to activated catalyst for $\mathrm{Rh}$ corresponds to the transition from Stage II to Stage III chemistry during slurry processing. This behavior was also reported by Ritter (1992) for the Defense Waste Processing Facility feed processing. Data from PNL confirm these observations for HWVP NCAW feed type. The data suggest that the $\mathrm{H}_{2}$ generation rate peaks observed just after transition to Stage III as indicated in the previous paragraph may be examples of $\mathrm{NO}_{2}^{-}$enhancing 
Rh catalytic decomposition of $\mathrm{HCOOH}$ at a critical $\mathrm{HCOOH} / \mathrm{NO}_{2}^{-}$mole ratio.

Samples taken following Stage III processing contained $\mathrm{NH}_{4}^{+}$consistent with Reaction (6). The total $\mathrm{CO}_{2}$ measured could be accounted for by assuming it was a result of $\mathrm{NH}_{3}$ and $\mathrm{H}_{2}$ production.

A fine-particulate, gray-black to black residue was observed during Stage III, Reaction (7). Semiquantitative analyses indicate that this material is enriched in the more "noble" metals contained in the slurry, such as $\mathrm{Pd}, \mathrm{Rh}$, and $\mathrm{Ru}$ as well as $\mathrm{Cu}, \mathrm{Ag}, \mathrm{Te}, \mathrm{Se}$, and $\mathrm{Pb}$. Pourbaix (1974) diagrams for the above elements indicate an elemental stability field under the test conditions observed during Stage III. However, the oxidation state of the residue elements has not been positively identified.

\section{Effect of Processing Variables on $\mathrm{H}_{2}$ and $\mathrm{NH}_{3}$ Generation}

Four processing variables: acid neutralization capacity, reduced $\mathrm{NO}_{2}^{\circ}, \mathrm{HCOOH}$ addition rate, and temperature were evaluated with respect to their effect on offgas and $\mathrm{NH}_{3}$ generation using the slurry described in Table I. Test 1 was used as a base case for comparison. Peak gas generation rates and the total amounts of gases measured are given in Table III.

Table III. Peak Gas Generation Rates and Total Amounts of Gas Measured During Nine Laboratory-Scale HWVP Feed Preparation Tests with an NCAW Simulant

\begin{tabular}{|c|c|c|c|c|c|c|c|c|c|}
\hline Test & 1 & 2 & 3 & 4 & 5 & 6 & 7 & 8 & 9 \\
\hline \multicolumn{10}{|l|}{ Total $(\mathrm{mM})$} \\
\hline $\mathrm{CO}_{2}$ & 907 & 989 & 696 & 631 & 784 & 830 & 665 & 730 & 454 \\
\hline NO & (a) & 56.5 & 40.3 & 122 & 492 & 441 & 466 & 369 & 0.7 \\
\hline $\mathrm{N}_{2} \mathrm{O}$ & 36.9 & 245 & 247 & 23.3 & 31.6 & 36.2 & 33.0 & 83.0 & 0.6 \\
\hline $\mathrm{H}_{2}$ & 106 & 48.0 & 2.70 & 98.0 & 77.0 & 74.0 & 69.0 & 69.0 & 53 \\
\hline $\mathrm{NH}_{3}{ }^{(b)}{ }_{1}$ & 64 & 44 & (c) & 52 & 64 & 71 & 41 & 32 & 54 \\
\hline $\mathrm{NH}_{3}{ }^{(\mathrm{d})}$ & 47 & 43 & 5.9 & $18^{(e)}$ & 50 & 46 & 27 & 21 & 43 \\
\hline
\end{tabular}

Peak Rate $(\mathrm{mM} / \mathrm{min})$

$\begin{array}{llllllllll}\mathrm{CO}_{2} & 12.6 & 9.1 & 8.7 & 7.1 & 7.0 & 7.8 & 5.8 & 2.9 & 7.1 \\ \mathrm{NO} & . \text { (a) } & 0.7 & 0.6 & 4.7 & 5.9 & 5.0 & 3.4 & 2.6 & 0 \\ \mathrm{~N}_{2} \mathrm{O} & 1.5 & 2.6 & 2.5 & 0.6 & 0.7 & 1.5 & 0.6 & 0.6 & 0 \\ \mathrm{H}_{2} & 0.8 & 0.5 & 0.03 & 1.34 & 0.9 & 0.4 & 1.0 & 0.7 & 0.30\end{array}$

(a) Detector problem - data unreliable

(b) Calculation based on quantity of $\mathrm{CO}_{2}$ released in excess of that accounted for by other observed reaction products during Stage III. The stoichiometry is based on Equation 8.

(c) Calculation not made because $\mathrm{CO}_{2}$ was being generated by the reaction of nitrite with $\mathrm{HCOOH}$ over the period of interest during this test.

(d) Ammonia was measured as $\mathrm{NH}_{4}{ }^{+}$in the slurry and condensate. Ammonia carried in the sweep gas downstream from the condensate trap was not measured.

(e) The reason for the discrepancy between the measured and calculated $\mathrm{NH}_{4}{ }^{+}$values is not known. The calculated value is consistent for other tests. 
To test increased acid neutralization capacity, $0.50 \mathrm{M}$ of $\mathrm{NaOH}$ was added to about $1.5 \mathrm{~L}$ of the slurry for Tests 2,3 , and 4 . Test 4 contained $30 \%$ nominal $\mathrm{NO}_{2}^{-}$to illustrate the effects of reduced $\mathrm{NO}_{2}{ }^{-}$concentration. The changes in these two chemical parameters resulted in three observable changes in the cifgas profiles as compared with the base line test and with each other. First, as illustrated by Figure 2, the increased basicity of Tests 3 and 4 delayed the drop in the system pH compared to Test 1 and consequently delayed the onset of carbonate decomposition by the amount of time needed to add $0.50 \mathrm{M}$ of $\mathrm{HCOOH}\left(0.50 \mathrm{M}_{\mathrm{NaOH}} / 0.0135 \mathrm{M}_{\mathrm{HCOOH}} / \mathrm{min}=36.6 \mathrm{~min}\right)$. Second, as illustrated in Figure 3, for equivalent amounts of $\mathrm{NO}_{2}^{-}$, reduction of $\mathrm{NO}_{2}^{-}$to $\mathrm{N}_{2} \mathrm{O}$ (Equation 3) is favored over NO generation (Equations 2 and 4) in the more alkaline systems (compare Tests 1 and 2). When the $\mathrm{NO}_{2}^{-}$concentration is reduced as in Test 4, the reaction between $\mathrm{HCOOH}$ and $\mathrm{NO}_{2}^{-}$again favors $\mathrm{NO}$ generation. \{Note that reduction of $\mathrm{NO}_{2}^{-}$to $\mathrm{N}_{2} \mathrm{O}$ (Equation 3) consumes twice the $\mathrm{HCOOH}$ as the reaction producing $\mathrm{NO}$ (Equation 4). This appears to buffer the slurry during Test 2 and would account for the $\mathrm{pH}$ remaining higher during that test.\} Third, as illustrated by Figure 4, at equivalent $\mathrm{NO}_{2}^{-}$concentration (Tests 1 and 2), a reduced $\mathrm{H}_{2}$ generation rate was observed in more alkaline systems. This may be related to the amount of undissociated $\mathrm{HCOOH}$, perhaps the key reactant in $\mathrm{H}_{2}$ production. The significantly higher peak $\mathrm{H}_{2}$ generation observed in Test 4 is attributed to the high $\mathrm{HCOOH} / \mathrm{NO}_{2}^{-}$ratio as discussed in the next section. Generation of $\mathrm{NH}_{3}$ did not show a strong trend with respect to $\mathrm{pH}$ or $\mathrm{NO}_{2}{ }^{-}$concentration in these tests. It appears that $\mathrm{pH}$ is a controlling factor for reaction pathways and that some critical concentration of $\mathrm{HNO}_{2} / \mathrm{NO}_{2}{ }^{-}$and $\mathrm{HCOOH}$ must be present in the slurry before some reactions will proceed.

\section{Reduced Nitrite Concentration}

Lower $\mathrm{NO}_{2}^{-}$concentrations were observed to yield higher $\mathrm{H}_{2}$ generation rates with approximately equivalent amounts of $\mathrm{HCOOH}$ added (compare Test 4 and Test 1 in Table III). When $\mathrm{NO}_{2}^{-}$is not added, as in Test 9 , the $\mathrm{H}_{2}$ generation is reduced, presumably because no $\mathrm{NO}_{2}^{-}$ was present to enhance the catalytic activity of $\mathrm{Rh}$. The amount of $\mathrm{NH}_{3}$ generated in the absence of added $\mathrm{NO}_{2}^{-}$was approximately the same as the baseline case (refer to Table III). It was expected that the amount of $\mathrm{H}_{2}$ generated would correlate better with the amount of $\mathrm{NH}_{3}$ generated than observed. The almost complete lack of $\mathrm{N}_{2} \mathrm{O}$ or NO during Test 9 indicated that the source of these oxides under the processing conditions is almost $100 \%$ due to $\mathrm{NO}_{2}^{-}$rather than $\mathrm{NO}_{3}^{-}$reduction.

\section{Reduced $\mathrm{HCOOH}$ Addition Rate}

The rate of $\mathrm{HCOOH}$ addition was reduced by a factor of 2.5 in Test 8 compared with the baseline case. The rate of $\mathrm{HCOOH}$ addition did not appear to have a significant effect on the rate of $\mathrm{H}_{2}$ generation or the total amount of $\mathrm{NH}_{3}$ generated (when compared with tests with equivalent amounts of $\mathrm{HCOOH}$ added). This is reasonable, because $\mathrm{H}_{2}$ and $\mathrm{NH}_{3}$ generation occurs primarily after $\mathrm{HCOOH}$ addition is completed. A generation rate that was proportional to the $\mathrm{HCOOH}$ addition rate was measured for gases that were generated during $\mathrm{HCOOH}$ addition $\left(\mathrm{CO}_{2}, \mathrm{NO}\right.$, and $\mathrm{N}_{2} \mathrm{O}$ ). 


\section{Correlation Between $\mathrm{pH}$ and $\mathrm{CO} 2$ Generation Rate \\ Profiles}

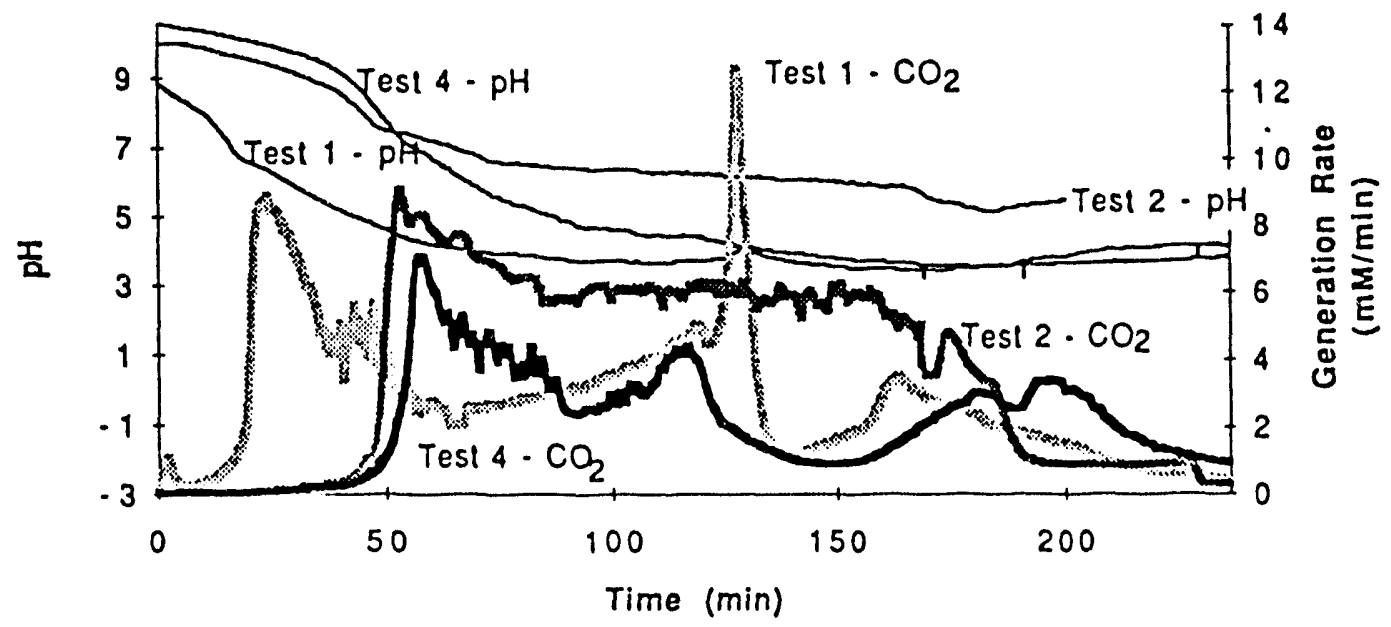

Figure 2. Comparison of Test 1 (Baseline) and Tests 2 and 4 (0.50 M NaOH Added) Showing the Delay of $\mathrm{CO}_{2}$ Generation Due to Added Base. Time is measured from the start of $\mathrm{HCOOH}$ addition for each test.

Nitric and Nitrous Oxide Profiles

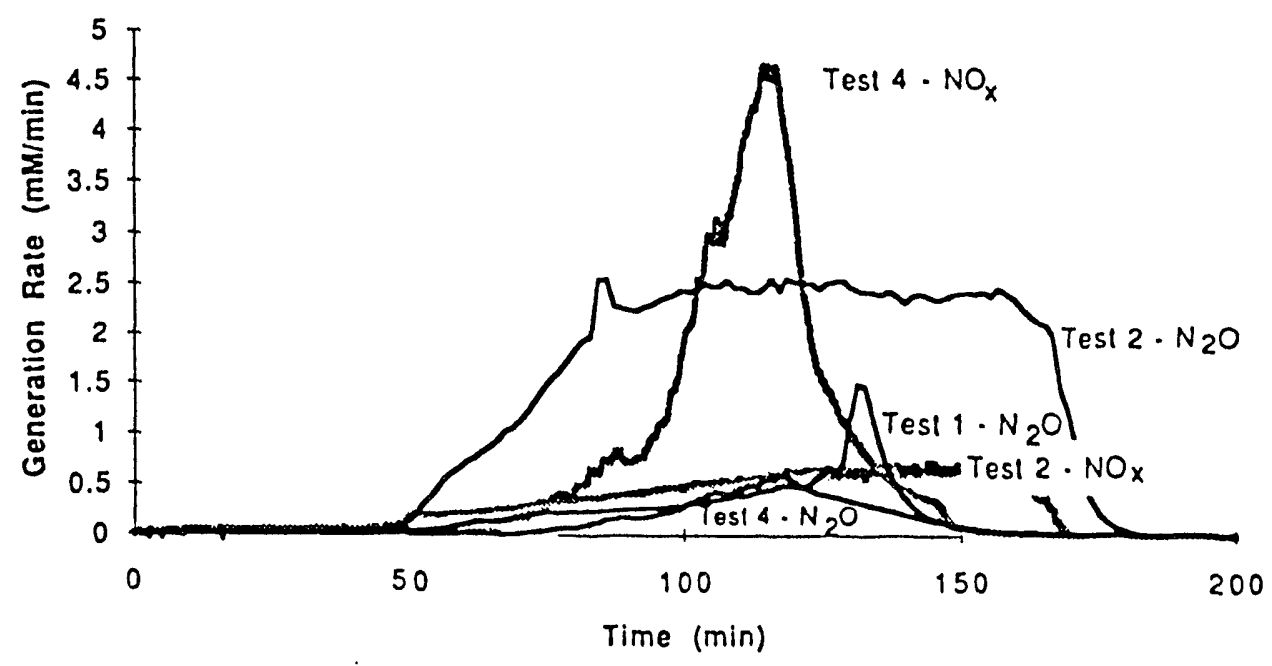

Figure 3. Comparison of the $\mathrm{NO}_{x}$ and $\mathrm{N}_{2} \mathrm{O}$ Offgas Profiles for Tests 1,2 , and 4. Time is measured from the start of $\mathrm{HCOOH}$ addition. The $\mathrm{NO}_{x}$ profile for Test 1 was not included because its shape has been distorted, and it would have been offscale on this diagram. 


\section{Hydrogen Generation Rate with Corresponding pH \\ Protiles}

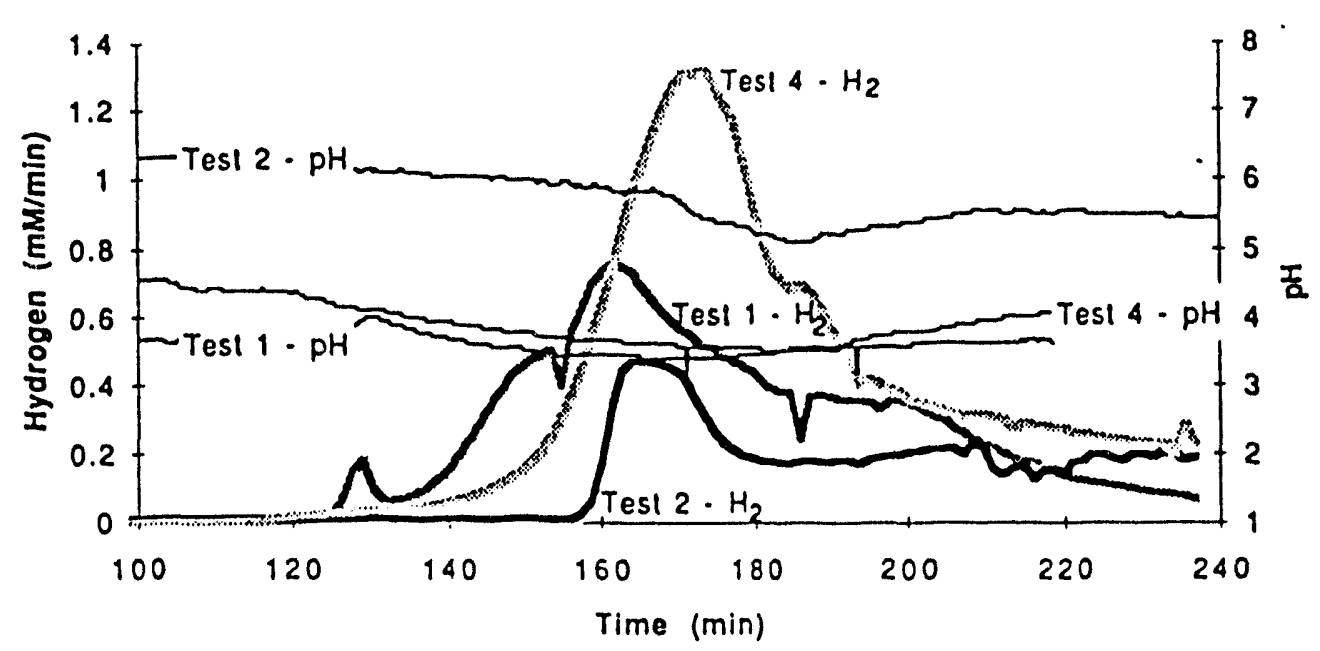

Figure 4. Comparison of the $\mathrm{H}_{2}$ Generation Peak Profiles for Tests 1, 2, and 4. Test 3 data were not included because the amounts of $\mathrm{H}_{2}$ generated were very small and would not show up on the scale of the diagram. Time is measured from the beginning of $\mathrm{HCOOH}$ addition.

\section{Reduced Processing Temperature}

The sensitivity of $\mathrm{H}_{2}$ peak generation rate to process temperature control was demonstrated in Tests 5,6 , and 7. These tests varied in the temperature at which $\mathrm{HCOOH}$ was added $\left(85^{\circ} \mathrm{C}, 85^{\circ} \mathrm{C}\right.$, and $75^{\circ} \mathrm{C}$ respectively) and the time interval between the end of $\mathrm{HCOOH}$ addition and of temperature ramp up to boiling ( $0 \mathrm{~h}, 2 \mathrm{~h}, 2 \mathrm{~h}$, respectively). The baseline case (Test 1$)$ was conducted at $95^{\circ} \mathrm{C}$ with immediate ramp up to boiling after $\mathrm{HCOOH}$ addition was complete. For Test $5\left(85^{\circ} \mathrm{C}\right.$, 0 -h hold), the reaction sequence was transitioning into Stage III (i.e., significant $\mathrm{H}_{2}$ generation was initiated) as the temperature ramp up was started. The $\mathrm{H}_{2}$ generation rate was comparable with the baseline case. For Test $6\left(85^{\circ} \mathrm{C}, 2\right.$-h hold), Stage III was initiated $1.6 \mathrm{~h}$ before temperature ramp up was started. Two $\mathrm{H}_{2}$ generation peaks were observed, before and after boiling. Both peaks were reduced by $\sim 50 \%$ compared with the baseline case. For Test $7\left(75^{\circ} \mathrm{C}, 2\right.$-h hold $)$, the reactions were significantly drawn out during Stage I and Stage II. For Test 7, the transition to Stage III occurred as the temperature ramp up was under way, resulting in a $\mathrm{H}_{2}$ generation rate comparable to the baseline case. The amount of $\mathrm{NH}_{3}$ generated was comparable to the baseline case for tests conducted at $85^{\circ} \mathrm{C}$, and slightly lower for the test conducted at $75^{\circ} \mathrm{C}$.

\section{CONCLUSIONS}

The peak generation rates of $\mathrm{CO}_{2}, \mathrm{NO}$, and $\mathrm{N}_{2} \mathrm{O}$ were found to be linearly proportional to the addition rate of $\mathrm{HCOOH}$.

The acid neutralization capacity of a slurry establishes a relationship for that slurry between the amount of acid added and the amount of other reactive slurry components present at a given $\mathrm{pH}$. This can lead to divergent reaction paths resulting in different $\mathrm{NO}_{2}^{-}$reduction mechanisms, a considerable difference in $\mathrm{pH}$ at the completion of $\mathrm{NO}_{2}{ }^{-}$reduction, and a clear difference in $\mathrm{H}_{2}$ generation rate in Stage III of the tests. The peak $\mathrm{H}_{2}$ generation rate was reduced in alkaline 
systems. At lower processing temperatures, the peak $\mathrm{H}_{2}$ generation rate was reduced. These studies suggest that process control parameters for the mitigation of $\mathrm{H}_{2}$ generation might include $\mathrm{pH}$ and temperature.

Hydrogen generation may also be reduced by maintaining the $\mathrm{NO}_{2}^{-}$concentration in the processing slurry above the critical level required for catalyst inhibition. This value will need to be quantified.

It is not clear from these studies that in the presence of noble metals, $\mathrm{NH}_{3}$ generation will be significantly reduced in the absence of $\mathrm{H}_{2}$ production.

\section{REFERENCES}

Peterson, M. E., R. D. Scheele, and J. M. Tingey, Characterization of the First Core Sample Of Neutralized Current Acid Waste From Double-Shell Tank 101-AZ, Pacific Northwest Laboratory, PNL-7758, September 1989.

Ritter, J. A., J. R. Zamecnik, and C. W. Hsu. "Hydrogen Generation During Treatment of Simulated High-Level Radioactive Waste with Formic Acid (U)." Proceedings of the Third International Conference High Level Radioactive Waste Management, Las Vegas, Nevada, April 12-16, 1992.

Helgesen, H. C. Thermodynamics of Complex Dissociation in Aqueous Solutions at Elevated Temperatures. J. Phys. Chem., v. 71, No. 10, p. 3121, 1967.

King, R. B., A. D. King, Jr., N. K. Bhattacharyya, C. M. King, and L. F. Landon. Noble Metal Fission Products as Catalysts for Hydrogen Evolution from Formic Acid Used in Nuclear Waste Treatment. Presented at the Washington American Chemical Society meeting 1993, to be published in Chemical Pretreatment of Nuclear Waste for Disposal W. W. Schulz and E. P. Horwitz, eds.

Wiemers, K. D. Evaluation of Process Off Gases Released During the Formating of Simulated HWVP Feed. Pacific Northwest Laboratory, PNL-SA-15965. Presented at the American Institute of Chemical Engineers National Meeting, Denver, Colorado August 21-24, 1988.

Pourbaix, M. Atlas of Electrochemica! Equilibria in Aqueous Solutions. National Association of Corrosion Engineers, Houston 1974. 

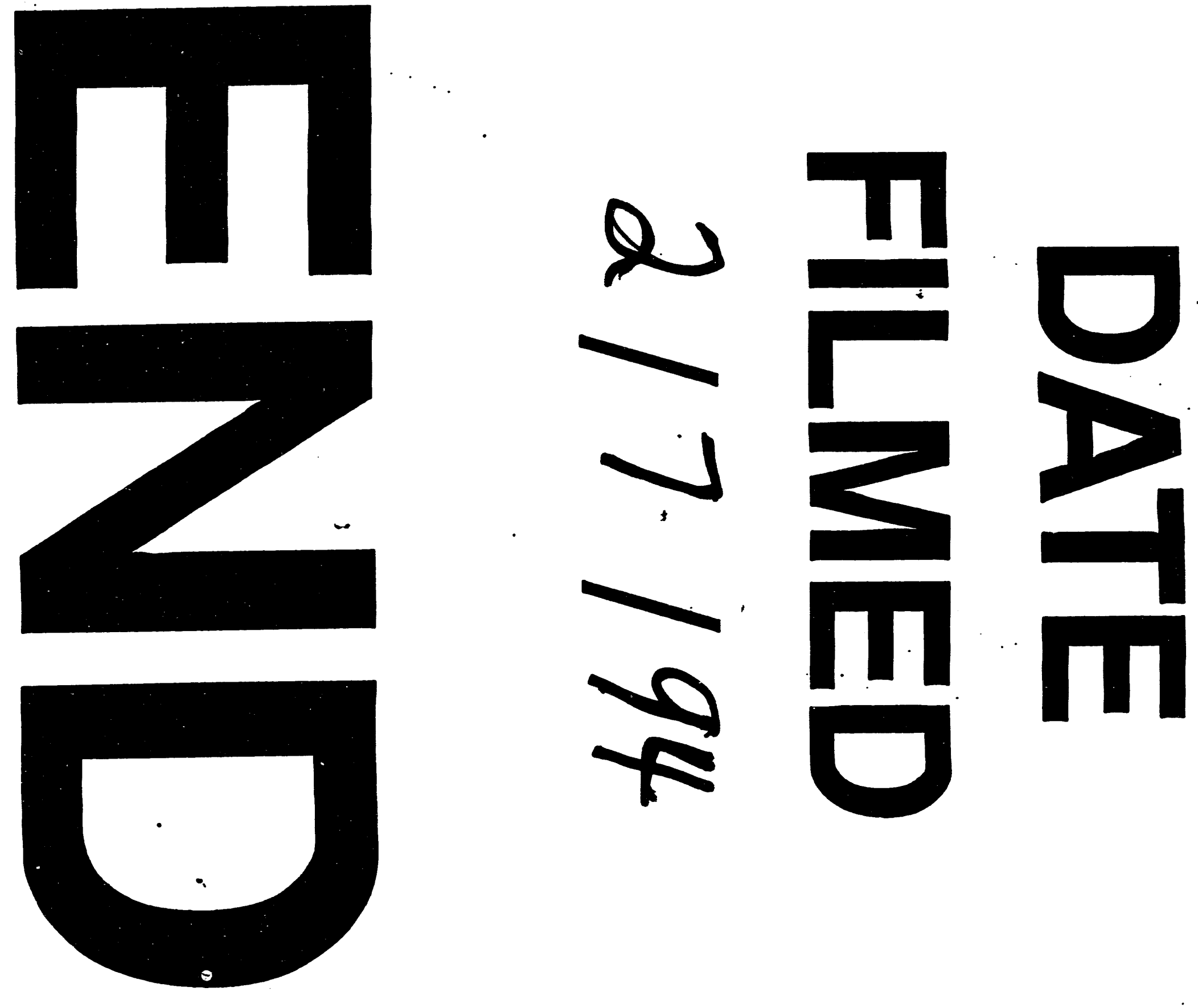